\title{
REDISCOVERY OF STICTOTARSUS MINIPI LARSON (INSECTA: COLEOPTERA: DYTISCIDAE) IN LAKE ATHABASCA, SASKATCHEWAN.
}

The predaceous diving beetle species Stictotarsus minipi Larson (Coleoptera: Dysticidae: Hydroporinae; Fig. 1, see inside front cover, bottom) was described on the basis of a single male specimen collected from the sandy shoreline of Anne Marie Lake in southern Labrador. ${ }^{1,2}$ The species has a number of unique features such as produced and scooplike clypeus, distally widened protibia, and a reduced prosternal process, and narrowed hind pronotal angles which provide increased fore-body flexibility. Larson postulated that these features represent adaptations for burrowing in loose sand along the wave-washed shorelines of larger lakes. ${ }^{1}$

A second specimen was collected in August 2000 on the south shore of Lake Athabasca, Athabasca Sand Dunes Provincial Wilderness Park, SK (G. Hutchings, pers. comm.). The specimen was found clinging to a stick on the sandy beach. In July 2004, Gordon Hutchings and I returned to Lake Athabasca Sand Dunes Park, where many specimens were collected in shallow water near the shore as well as in beach lagoons. The water beetle Oreodytes laevis Kirby (Coleoptera: Dytiscidae) was a cooccurring species, as it was in its type locality. ${ }^{1}$

Larson postulated that $S$. minipi may have a wide distribution on sandy lake shores across the boreal region of North America. ${ }^{1}$ However, the record from Lake
Athabasca also raises the possibility that the range could be disjunct, with isolated populations in sandy areas of south-central Labrador and in the Athabasca sand dune complex of northern Saskatchewan and Alberta. The sand-associated tiger beetle Cicindela limbata hyperborea Wallis (Coleoptera: Carabidae; Fig. 2, see inside front cover, bottom) apparently has such a disjunct distribution, with a big gap occurring between northern Saskatchewan and southern Labrador. It has been postulated that these two populations are specifically distinct based on colour pattern, but there seems to be no grounds for this separation, as similar colour patterns occur in both areas.

An interesting question for biogeographers is whether this disjunction in the range of these sand specialists is real, due to the rarity or lack of suitable sandy habitat in intermediate areas? Or is it the result of inadequate collecting in boreal Canada? Might these be members of a larger sand-dwelling community with a similar distribution?

1. Larson DJ (1991) A new species of Potomonectes Zimmerman (Coleoptera: Dytiscidae) from Labrador. The Coleopterist's Bulletin 45:280-284.

2. Larson DJ, Alarie Y, Roughley RE (2000) The predaceous diving beetles (Coleoptera: Dytiscidae) of the Nearctic Region, with emphasis on the fauna of Canada and Alaska. NRC Research Press, Ottawa, ON.

- Ronald R. Hooper ${ }^{\dagger}$, Royal Saskatchewan Museum, Regina, SK 